\title{
HATÁROKON ÁTNYÚLÓ TERMÉSZETVÉDELMI TERÜLETEK LEHETÓSÉGEI ÉS PROBLÉMÁI
}

\author{
GÁLOSI KOVÁCS BERNADETT-HORVÁTH GERGELY
}

PERSPECTIVES AND PROBLEMS OF TRANSBOUNDARY PROTECTED AREAS

\begin{abstract}
There are several regions of the world where protected areas or areas with natural values worthy of protection are adjacent to each other. Currently, several national organizations, among others such as the International Union for Conservation of Nature and the EUROPARC Federation, deal with the questions of these transboundary protected areas, the connections of which are varying, ranging from loose co-operation to integrated organization. While the state borders in the Carpathian Basin are mostly artificial, and thus dissect uniform landscapes and physiognomic units, it is not surprising that Hungary and its neighbouring countries have several adjacent or transboundary protected areas. In some cases-for example the Neusiedler See-Seewinkel-FertóHanság region and the Aggtelek Karst-Slovak Karst region-transboundary UNESCO World Heritage sites, biosphere reserves, Ramsar wetlands, and national parks can be found along the border. Regarding the latter karst region, the nature of co-operation and different perspectives are analyzed in this paper, and similarly also the case of the transboundary Novohrad-Nógrád Geopark. It can be stated that, in spite of the good co-operation of the parties, the different laws, administration, and financial assistance, as well the infrastructural backwardness that is linked to their peripheral status, causes difficulties with respect to unification. Nevertheless, these transboundary protected areas offer good opportunities for the local regional development, especially due to ecotourism and geotourism. Therefore, it is worth emphasising and broadening the transboundary co-operation based on nature conservation.
\end{abstract}

Keywords: geoheritage, nature conservation, protected areas, geopark

\section{Bevezetés}

A természeti és a - tôlük gyakran elválaszthatatlan - kulturális értékek védelme a Föld országaiban sehol sem egyszerú és könnyú feladat. A politikai vezetők ugyanis helyi és országos szinten egyaránt általában hajlanak arra, hogy a gyorsan és közvetlenül hasznot hozó tevékenységeket támogassák, és az anyagi haszonnal nem, vagy csak hosszabb távon kecsegtető minden egyéb kérdést félretegyenek majdani ,,jobb időkre”. Márpedig az értékvédelem sajnos minden szép szólam ellenére inkább eme második kategóriába tartozik. Még nehezebb a védelem, ha a védendó érték több országhoz tartozik, ha azt politikai határ választja ketté, mivel az értékvédelem igen nagy részben jogi és (köz)igazgatási szabályozásokon alapul, amelyek viszont a különféle integrációk gomba módra való szaporodása ellenére sok helyütt még nem vagy alig közelítenek egymáshoz. A természeti és kulturális értékek azonban egy területen jól „,forintosíthatók”, mert - mint sok szempontból érdeklődést keltő területek - jelentôs turizmust vonzhatnak, annak gazdasági előnyeit elvileg mindkét fél lefölözheti.

Érdemes ezért megvizsgálni, milyen szervezeti és szakmai háttérrel rendelkeznek az ilyen területek, milyen problémák vetődnek fel a határokon átnyúló természeti értékek védelme, kezelése, menedzselése, turisztikai hasznosítása stb. terén. (Noha itt a szó szoros - jogi, igazgatási stb. - értelmében nem feltétlenül természetvédelmi területekről van szó, hanem határokon átnyúló, megôrzésre és védelemre méltó természeti értékekkel rendelkező területekről, az egyszerúség és könnyebb olvashatóság érdekében ezeket a továb- 
biakban röviden határokon átnyúló természetvédelmi területeknek nevezzük.) A probléma azért is jelentős, mert ilyen értelemben a Földön meglepően sok határ menti, szomszédos védett területtel érintkező, vagy éppen határon átnyúló védett terület található. A Kárpátmedence közepén elterülő Magyarország esetében pedig - ahol a politikai határok szinte kivétel nélkül természeti és táji egységeket szelnek át, azaz a tájak, földtani képződmények, elterjedési területek és élőhelyek az államhatárokon túl folytatódnak - különösen érdekes és fontos a helyzet legalább részleges vizsgálata.

\section{A határok és a határokon átnyúló védett területeket koordináló szervezetek szerepe}

Határmentiséget, határon átnyúló egységeket vizsgálva természetesen röviden érinteni kell maguknak a határoknak a kérdéskörét is. Bár a határok földrajzi problémáival, jelentőségével számtalan tanulmány foglalkozott (csak a hazai szerzők közül és a teljességre való törekvés igénye nélkül néhányat kiemelve TóTH J. 1996, 2011, NEMES NAGY J. 1998, HARDI T. 2000, Kocsis K. 2004, BARANYi B. 2007, 2014; CsÜllÖG G. 2008; PAP N. - Tóth J. 2008, HoRvÁth G.-CsüllöG G. 2014 stb.), amelyek természetesen nem vonatkoztathattak el a természetföldrajzi adottságoktól, mégis leginkább társadalom- vagy történeti földrajzi megközelítésúek. A természeti határok esetében a tájak elhatárolásának kérdése kerül gyakran elő, de főként a természeti tájak rendszertani felosztásához és a tájnevekhez kapcsolódóan (Prinz Gy. 1936, KádÁr L. 1941, Bulla B. -Mendöl T. 1947, Marosi S. - Somogyi S. 1990, Hajdú-Moharos J. - Hevesi A. 1997, Paládi-Kovács A. 2003, Kocsis K. 2006, LuKács L. 2006, DövÉNYI Z. 2010, FARAGÓ I. 2014 stb.) és csak kisebb mértékben a tájhatárok kijelölésének elméleti hátterére vonatkozóan (pl. CsorBA P. 2008, MEzôsı G. - BATA T. 2011).

A földrajz értelmezésében a határ a térfelosztás mesterséges eszköze, amely megjelenhet egyrészt elválasztó térelemként, valamilyen formában kifejezett gátként, mint például bizonyos természeti elemek által kijelölt, vagy a rögzített államhatárok esetében; másrészt szűrőzónaként, ahol nem élesen jelzett az elválasztás; valamint ütközőzónaként, mint a térben előrehaladó folyamatok mozgó peremzónája (NEMES NAGY J. 1998). Más szempontok alapján földrajzi helyzet szerint lehet szárazföldi, tengeri, folyóvízi határ, alaktani szempontból lehet szabályos geometriai vagy szabálytalan futású, stabilitás szerint lehet állandó vagy mozgó, az átjárhatóság szerint nyitott vagy zárt, a kapcsolati jelleg szerint együttmúködő vagy elzárkózó. Jogi megközelítésben a határ lehet legális, nemzetközileg elismert, lehet az egyik fél által vitatott, el nem ismert, de valójában de facto létezó, vagy lehet fiktív, azaz bizonyos térképeken megjelenő, de a valóságban nem létező (PAP N.-Tóтн J. 2008, Kocsis K. 2006).

A természeti határok, különösen egy táj határa igen nehezen jelölhető ki. MEzősI G. -BATA T. (2011) ZADEH. L. A. (1965) nyomán a tájhatárokat „fuzzy” típusú határokként értelmezi, ami leegyszerúsítve azt jelenti, hogy a határ nem egy éles vonal, hanem egy bizonytalan szélességú sáv, amely mentén a két szomszédos táj fokozatosan megy át egymásba. A nehezen kijelölhető határok tehát keskenyebb-szélesebb (esetleg akár több km széles) ökotonokként értelmezhetők. A természet persze nem ismer politikailag kijelölt határokat, ám azok helyzetét vizsgálva az is látható, hogy jelentőségük gyakran változik: hol nő, ami miatt a határok általában nehezebben lesznek átjárhatók, hol csökken, ami által egyre inkább átjárhatóvá válnak, de utóbbi esetben sem jelentéktelenednek el, mivel egy adott ország törvényeinek hatálya az illető ország államhatáráig terjed. Ez utóbbi igen fontos tény, amitől határon átnyúló védett területek esetében nem lehet elvonatkoztatni, és gyakran igen megnehezíti az együttmúködést. 
A politikai határok tehát gyakran elválasztanak, ennek ellenére - ahogy fentebb is említettük - a Földön meglepően sok határon átnyúló, valamilyen védelem alatt álló, vagy valamilyen (a védelmet is elősegítő) státuszú lehatárolt egységhez tartozó, egymáshoz több-kevesebb szervezettséggel kapcsolódó terület (Transboundary Protected Area, TBPA) található. Az e tárgyban a Természetvédelmi Világszövetség vagy Nemzetközi Természetvédelmi Unió (International Union for Conservation of Nature, IUCN) honlapjáról elérhető utolsó részletes lista (LYSENKO, I. et al. 2007) 227 tételt tartalmaz, és ez a szám az elmúlt évtizedben nyilvánvalóan még jelentôsen növekedett is. A földrészek szerint megoszlást - kiterjedés alapján - az 1. táblázat tartalmazza. Mint látható, valóban meglepően nagy a határon átnyúló védett területek kiterjedése.

1. táblázat - Table 1

Határon átnyúló védett területek földrészek szerinti megoszlása (LYSENKO, I. et al. 2007) Distribution of transboundary protected areas by continents (by LYSENKO, I. et al. 2007)

\begin{tabular}{lc}
\hline Földrész & \multicolumn{1}{c}{$\begin{array}{c}\text { Terület } \\
\left(\mathrm{km}^{2}\right)\end{array}$} \\
\hline Európa & 188153,30 \\
Ázsia & 570505,86 \\
Afrika & 931617,95 \\
Észak-Amerika & 1511627,08 \\
Közép- és Dél-Amerika & 1424697,66 \\
Összesen & 4626601,85 \\
\hline
\end{tabular}

Léteznek olyan nemzetközi szervezetek, amelyek kimondottan ezekkel a határon átnyúló területekkel foglalkoznak. Két példát kiragadva az egyik a fentebb említett IUCN. A svájci Glandban székelő szervezet fó feladata, hogy elősegítse a biodiverzitás megőrzését, a természeti erőforrások mértékletes használatát és az ökológiai rendszerek fenntartását. Ennek egyik részlege 1997 óta a Védett Teriuletek Világszervezete (World Commission on Protected Areas, WCPA), amely létrehozta a Határokon Átívelö Globális Természetmegórzési Hálózatot (Global Transboundary Conservation Network); a Hálózat egyik tevékenysége például, hogy szakértő személyeket, illetve szakmai irányítást kínál a határokat átívelő, tájökológiai szemléletű (CHASSOT, O. 2011) természetvédelmi tervezés, menedzselés és kezelés terén. Ehhez rendelkezésre áll egy önálló tudományos szervezethez hasonlóan szervezett felépítettségű, több mint 60 ország mintegy 200 szakértőjét tömörítő különleges csoport (Transboundary Conservation Specialist Group) is. Számos kiadványt is megjelentettek a határon átívelő természetvédelem témakörében (SANDWITH, T. et al. 2001, VASILIJEVIĆ, M. et al. 2015)

Egy másik - magát kimondottan európainak meghatározó - szervezetként hasonló célokat követ a már valamilyen státusszal rendelkező, intézményesült szerveződéseket (természetvédelmi területek, nemzeti vagy egyéb szintû parkok, natúrparkok stb.) összefűző EUROPARC Federation (amelynek jelszava, hogy „,a természet nem ismer határokat”). Feladatának tekinti a védett területek kezelésének, menedzselésének minden területén a nemzetközi együttmúködések előmozdítását, többek között a Határokon átívelő parkok (Transboundary Parks) program révén. A program részeként 2007-ben egy hálózat jött létre, a Transboundary Network vagy rövidítve TransParcNet, amelynek céljai többek között a tapasztalatok és az ún. „legjobb gyakorlatok” cseréjére, kölcsönös megismertetésére, 
tematikus munkacsoportok kialakítására, személyzetek cseréjére, tanulmányútjára, konferenciák, szemináriumok, múhelyek szervezésére, információs anyagok megjelentetésére, támogatások szerzésére, a már említett TBPA-k érdekérvényesítésének elősegítésére, valamint a TBPA-k közötti projektek koordinálására irányulnak. Évente valamely más helyen a TransParcNet több napos ülést tart, amelynek során a határokon átívelő programokban részt vevő szakemberek osztják meg egymással tapasztalataikat. Legutoljára 2018-ban a 10. ülésen a csehországi Podyjí és az ausztriai Thayatal Nemzeti Parkok voltak a házigazdák, 14 országból 70 résztvevő volt jelen, és a fő megvitatott téma az éghajlatváltozás hatása volt. A hálózathoz mintegy 850000 ha terület tartozik, ebből több mint 280000 ha Natura 2000 terület, és mintegy 1000 főnyi személyzetet foglalkoztatnak.

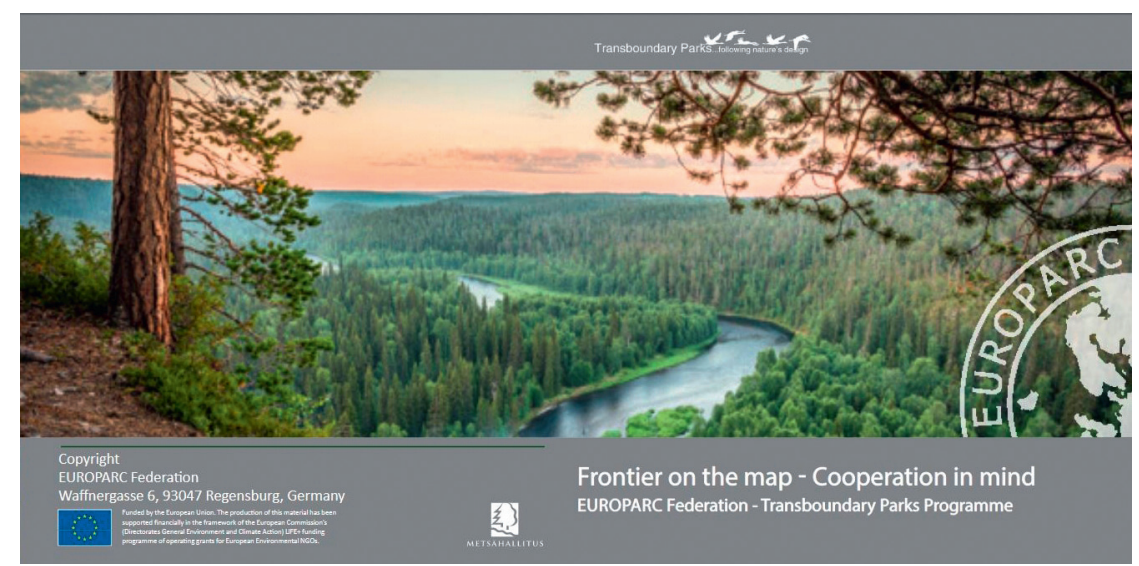

1. ábra Az EUROPARC Szövetség Határokon átívelő parkok programját ismertető szórófüzetke részlete Figure 1 Excerption of the flyer of the Transboundary Parks Programm of the EUROPARC Federation (https://www.europarc.org/wp-content/uploads/2015/07/Flyer-EUROPARC-Transboundary-Parks-Programme.pdf)

Tudományunk szempontjából e pozitívnak tűnő összkép azonban mégis kissé csalóka, mert ha gondosan átolvassuk a nevezett szervezetek honlapjait, kiadványait, tanulmányozzuk a programjaikat, akkor azt láthatjuk, hogy az elsődleges cél az élővilág sokféleségének, a biodiverzitásnak a védelme, és csak ritkán találkozhatunk a földtudományi (földtani, felszínalaktani, víztani, talajtani) értékek védelmével, sőt akár megemlítésével. Jól jellemzi ezt a helyzetet az IUCN egyik alapvető kiadványának (SANDWITH, T. et al. 2001) azon bevezetó meghatározása, amely szerint a határon átnyúló védett terület egy olyan egyértelmúen lehatárolt földrajzi tér, amely egy vagy több nemzetközi határon át ökológiailag összekapcsolt, és magában foglal számos együttmúködési formát. Azaz a „geo” szó csak olyan értelemben kerül elő, hogy a vizsgált területek valamiféle földrajzi egységek (tájak, régiók, közigazgatási egységek). Természetesen van kivétel, például az IUCN megjelentetett földtani-felszínalaktani témakörben is néhány kiadványt a természeti világörökségekhez kapcsolódóan (WiLliams, P. 2008, WooD, C. 2009 stb.), és az IUCN WCPA alszervezeten belül is alakult a földtudományi értékek megórzésével foglalkozó önálló csoport (Geoheritage Specialist Group), ennek ellenére az arányok rendkívül torzak. Szerencsére vannak olyan nemzetközi szervezetek is, amelyek a földtudományi természetvédelmet tekintik hivatásuknak, közülük kiemelendő a röviden ProGEO néven ismert, a földtudományi örökség megórzésére alakult európai egyesület (European Association for the Conservation of the Geological Heritage). A ProGEO tagja a földtani értékek megőrzését természetesen szívügyének tekintő Nemzetközi Földtani Uniónak (International 
Union of Geological Sciences, IUGS) és társult tagja a már említett Természetvédelmi Világszövetségnek (IUCN). A ProGEO indította el a Springer Kiadónál azt a mára már nemzetközi rangúvá vált Geoheritage címú folyóiratot, amely a Föld minden részét érintő tanulmányokat közöl a földtudományi értékek védelmérool, és áttekintő kiadványt (Wimbledon, W. A. P. - Smith-Meyer, S. 2013) is megjelentetett a földtudományi természetvédelem európai helyzetéről. Ki kell még emelni az ENSZ Nevelésügyi, Tudományos és Kulturális Szervezete (United Nations Educational, Scientific and Cultural Organization; UNESCO) földtudományi kutatásokat és értékvédelmet szolgáló tevékenységét, amelyen belül különösen fontos a Nemzetközi Földtudományi és Geopark Program (International Geoscience \& Geoparks Programme, IGGP) és a hozzá kapcsolódó Globális Geopark Hálózat (Global Geopark Network, GGN).

\section{Határokon átnyúló, megőrzésre és védelemre méltó területek típusai}

Az IUCN WCPA csoportosítása szerint négy típus különíthető el.

a) Határokon átnyúló védett területek (Transboundary Protected Areas, TBPA). Ezek meghatározása szó szerint azonos a fentebb olvasható, SANDwiTH, T. et al. (2001) által megfogalmazottal, azaz olyan egyértelmúen lehatárolt földrajzi terek, amelyek egy vagy több nemzetközi határon át ökológiailag összekapcsoltak, és magukban foglalnak számos együttmúködési formát. Érdekesség, hogy az IUCN honlap ennek fó példájaként az osztrák-magyar Neusiedler See-Seewinkel / Fertő-Hanság Nemzeti Parkot említi, amelyet egyébként 2003-ban az EUROPARC elsőként nyilvánított határon átnyúló parkká.

b) Határokon átnyúló (szárazföldi vagy tengeri) tájvédelmi területek (Transboundary Conservation Landscapes or Seascapes). Olyan egy vagy több nemzetközi határon át ökológiailag összekapcsolt területek, amelyek mind védelem alatt álló, mind eróforrások szempontjából változatosan hasznosítható területeket tartalmaznak, és magukban foglalnak számos együttmúködési formát. Példaként a Benin, Burkina Faso és Niger határán fekvő, az UNESCO világörökséghez tartozó folyó menti szavannaövezetet, a W-Arly-Pendjari regonális parkot, valamint az Oroszország, Kína, Kazahsztán és Mongólia „,négyeshatáránál” fekvő Altaj-Szaján ökorégiót említi.

c) Határokon átnyúló vándorfajvédelmi területek (Transboundary Conservation Migration Areas). Olyan két vagy több országot érintő élőhelyek, amelyek fennmaradása szükséges a vándorló fajok populációjának megőrzéséhez, és magukban foglalnak számos együttmúködési formát. Tanzánia és Kenya határán fekvő Serengeti Nemzeti Parkot és Maszáj Mara Nemzeti Rezervátumot, a holland, német és dán tengerpartot övező Watttengert, valamint a mauritániai, Atlanti-óceán parti Banc d'Arguin Nemzeti Parkot említi.

d) Önálló, speciális megjelölésként, negyedik típusként említi a Béke Parkot (Parkfor Peace), amely bármely fenti három típusra vonatkoztatható, és a békének, az együttmúködésnek van szentelve. Példa rá a Kanada és az Egyesült Államok határán fekvő WatertonGlacier Nemzetközi Békepark, amely 1932-ben jött létre a kanadai Waterton-tavak Nemzeti Park és az egyesült államokbeli Glacier Nemzeti Park egyesítésével. Mindkét park bioszféra-rezervátum, és közös területük a Világörökség része. 1997-ben Dél-Afrikában is bevezették a kategóriát, pontosabban egy nonprofit alapítványt (Peace Parks Foundation) hoztak létre határokon átnyúló, védendő területek (transfrontier conservation areas, TFCA) ugyancsak békeparknak nevezett kialakítására. Pool, C. (2006) szerint a békeparkok és a határokon átnyúló védett területek (TBPA) között csak annyi a különbség, hogy a békeparkok célja az is, hogy az országokat elválasztó határok mentén elôsegítsék a békét és 
az együttmúködést. Írásában - FULLER, S. (2004) alapján - 110 ország 169 békeparkját említi, köztük egymással igen feszült viszonyban lévő országok (pl. India és Pakisztán) határán kialakított parkokat, de ide sorolja a két Koreát elválasztó demilitarizált övezetet is, és kiemelten fontosnak tartja ezeknek a békeparkoknak a szerepét a sokszor egymással igen rossz viszonyban lévő afrikai országok esetében.

Célszerúbbnek látszik azonban, ha a fenti tagolás helyett a magyar hivatásos természetvédelem által használt kategóriákat használjuk, eszerint a határokon átnyúló teljes egészében védett, védett részleteket tartalmazó, vagy megőrzésre és védelemre méltó területek lehetnek - közös vagy csatlakozó - nemzeti parkok, tájvédelmi körzetek, világörökségi helyszínek, ramsari vizes élöhelyek, bioszféra-rezervátumok, geoparkok és natúrparkok, valamint olyan területegyüttesek, amelyek a fentiekből több típust is magukban foglalnak.

\section{Példák határokon átívelő védett területeken folyó jól múködő együttmúködésekre}

Az 1. táblázat szerint Európában a legkisebb a határokon átívelő védett területek kiterjedése, de általában a legjobb a szervezettségük és az együttmúködésük. Ugyanakkor az együttmúködéseket vizsgálva megállapítható, hogy annak szintje igen változó a gyakorlatilag egységesült szervezetektől a formailag elkülönülő, de azért jól integrált változatokon át az egymás mellett létező, csak alkalmi közös programokat szervező típusokig.

A legmagasabban integrált szintre jó példa a holland-német határon, azon belül ÉszakRajna-Vesztfália és Limburg tartományok határán fekvő, 1976-ban alapított MaasSchwalm-Nette Természeti Park, amely három folyóról kapta a nevét, és közel 800 km²-es területén erdőségek, fenyérek, hangás pusztaságok, lápok váltakoznak gondosan ápolt kultúrtájakkal. A park mintegy nyolcada Natura 2000-es terület. Elsősorban rekreációs és turisztikai terület, amely mind vezetett, mind önálló szervezésú gyalog-, lovas- és kerékpártúrákkal könnyen bejárható, kedvező vízisport-lehetőségeket biztosít, miközben a látogatóknak módja nyílik az élővilág megismerésére, helyi különlegességek kóstolgatására és az ott lakók vendégszeretetének élvezetére is. Különlegessége, hogy 2002 óta a határt átívelő parkot egy projektiroda egységesen igazgatja a hollandiai Roermondból, tehát nincs külön-külön német és holland vezetés, egyetlen menedzsment irányítja a projekteket és az egyéb tevékenységeket. A határ lényegében megszűnt, alig felismerhetô, és a park vezetésének célja egy kölcsönös „határon átnyúló identitás” kialakítása mind a helyiek, mind a turisták körében.

Egy kevésbé integrált szintre példa az egykori vasfüggöny keleti oldalán, Németország és Csehország határvidékén található, a földtani-természetföldrajzi szempontból egységes Elbai-homokkőhegységet alkotó Szász- és Cseh-Svájc területe, ahol már 1956-ban, illetve 1972-ben kialakítottak természetvédelmi területeket, de ezek egymástól függetlenül múködtek a politikai fordulatig. Az 1990-es években mindkét ország új, nagy kiterjedésú nemzeti parkokat alapított, elsősorban a térség földtani-felszínalaktani értékeire alapozva, természetesen az élővilág értékeit és a kulturális örökséget is hasznosítva. Az együttmúködés alapjait lerakva 1991-ben a két ország miniszterei írtak alá szerződést, majd 2004-ben egy közös stratégiát dolgoztak ki, amihez minden évben egy az együttmúködés elemeit részletező munkaterv készült. Ennek részei pl. közös tudományos projektek (digitális terepmodellek kidolgozása, egységes térképezés, ritka növény- és állatfajok kataszterezése, kihalt fajok visszatelepítése vagy kihalóban lévő fajok megmentése) és közös PR-tevékenység (információs anyagok, látogatóközpontok, a nagyközönség számára vezetett, határokat átszelő 
túrák mindkét országból toborzott túravezetőkkel), amelyeknek fontos eleme a kölcsönös kétnyelvúség, valamint a szervezetileg elkülönülő parkok látványelemeinek azonos megjelenítése (egységes „dizájn”). Természetesen mindezek mellett a „határtalanság” egyik legfontosabb létező előfeltétele a két ország hivatásos természetvédő intézményeinek és szakembereinek hagyományosan nagyon baráti kapcsolata.

\section{Magyarország természeti öröksége és a határok}

A Kárpát-medence központi és nyugati részén elterülő Magyarország nagytájai szinte kivétel nélkül folytatódnak az országhatáron túl is, ez a tény kiemeli a nemzetközi összefogás jelentőségét a természetvédelemben is. A medencejelleg, az eltérő éghajlati hatások és a változatos földtani adottságok következtében az ország növény- és állatföldrajzi képe nagyon változatos (VARGA Z. 2000, FODOR I. 2008, FODOR I. et al. 2012), területén nagy számban élnek atlanti, szubatlanti, mediterrán, illír, kontinentális, alpesi és kárpáti eredetú fajok, ugyanakkor magas a bennszülött (endemikus) fajok száma is. A Kárpátok a Kárpát-medencével együtt bővelkedik olyan fajokban, amelyek tőle északra és nyugatra Európában már egyáltalán nem, vagy alig fordulnak elő. A medencehelyzet nemcsak sokszínúséget, hanem különleges egységet, egyediséget is magában hordoz. Egy sajátosan magyar bioregionális egységet, a pannon régiót (Pannonicum) mondhatjuk magunkénak. A pannon régió mint önálló biogeográfiai régió európai uniós elismerése is azt jelzi, hogy jelentôs természeti tôkével járulunk hozzá az Unió természeti értékeihez. Földrajzi helyzetünk a környező biogeográfiai régiókkal való szerves kapcsolat folytonosságát is feltételezi, amely Európának is fontos (Carpathians Environment Outlook 2007). Különös értéket ad a térségnek a Kárpátok hegyvidéki területei és a Kárpát-medencét kitöltô alföldi fajok migrációjának biztosítása.

A Kárpátok által körülzárt térséget, amelynek területén erősen felszabdalódik a KeletEurópára még jellemző meglehetősen homogén zonalitás, természeti értékekben különösen gazdag kistájak színes sokasága jellemzi. Kiemelkedő a faji sokféleség a Kárpát-medencének azon peremterületein, ahol többirányú hatások összegződnek, ilyen az Alpokalja, ahol a keleti-alpesi, az illír és a pannon hatások találkoznak, az Északnyugati-Kárpátok előterében a Gömör-Tornai-karszt kárpáti, pannon és szubmediterrán hatásokkal, illetve a Bereg-Szatmári-sík, ahol már keleti-kárpáti (dacikus) hatások is jelentkeznek. Jelentős a faji sokféleség minden olyan területünkön, ahol a szubmediterrán hatás számottevő, mint pl. a Villányi-hegységben és a Mecsekben, mert ott megjelennek a holo- és északi mediterrán, pontomediterrán fajok is (FODOR I. et al. 2012). Ezek jórészt olyan térségek, amelyeket a 20. század első fele óta politikai határok választanak ketté.

Természeti örökségünk gazdagságát gyarapítja a természet „élettelen” értékeinek változatossága is. A különböző időszakokban és képződési feltételek mellett létrejött kőzettípusok, a kőzeteket alkotó ásványok, az ősmaradványok, valamint a felszínformáló erők hatására kialakult egyedi formák és formaegyüttesek a Kárpát-medence több száz millió évre visszakövethető földtörténeti múltjának és az élővilág fejlődésének változatos emlékeit őrzik, egyúttal ásványi nyersanyagként meg nem újuló természeti erőforrást jelentenek a gazdaság számára.

1989 előtt országhatáraink környezete - politikai okokból nehezen megközelíthető voltuk következtében - kevesebb emberi hatásnak volt kitéve, ami segítette a természetes ökológiai állapot megőrzését, a biodiverzitás, a természeti, táji, kulturális sokszínúség fennmaradását, ugyanakkor az elzárt határsávok egyik negatív következménye volt a tudományos kutatás elmaradása. A korábbi feltárás hiánya miatt nem lehet tudni, hogy 
a természetes élőhelyek mekkora kiterjedésűek lehettek, milyen fajok jelentek meg vagy tűntek el végérvényesen. Ma a könnyebben átjárható politikai határokon átnyúló ökológiai kapcsolatok - mint ökológiai folyosók - a vadon élő élővilág természetes élőhelyekre való be- és visszatelepülésének, rendszeres vándorlásának, illetve a genetikai sokféleség fennmaradásának forrását biztosítják, és a határok „légiesedése” segíti a földtudományi örökség feltárását, védelmét és megismertetését is. Ezért van kiemelt szerepük a természeti értékek védelmét szolgáló nemzetközi, így a határ menti együttmúködéseknek is.

\section{Magyarország és szomszédjai közötti határokon átnyúló védett területek}

Magyarország és szomszédjai vonatkozásában a trianoni békediktátum, majd a szovjet megszállás okozta történelmi meghatározottság miatt az eltelt utolsó közel száz év során a határok sokkal inkább elválasztó, mintsem összekötő, egységesítő szerepet játszottak. A Kárpát-medencei egységes tájak feldarabolódtak, elkülönültek, a határ menti együttmúködések minimálisak, sőt kifejezetten tiltottak voltak. Ezt a helyzetet csak a rendszerváltozás és az Európai Unióhoz való csatlakozás oldotta úgy-ahogy, de még mindig nem kielégítően. Ahogy arra BARANYI B. (2015) rámutat, ,az interregionális együttmúködés új típusú intézményi struktúrái nemcsak a külső perifériák felszámolásához, az elmaradott határrégiók felzárkóztatásához és a kohéziós folyamatok elmélyítéséhez jelenthetnek hatékony hozzájárulást..., hanem a határok nélküli együttmúködés erősítéséhez... a határ mentiség új dimenziói elsősorban a kisebb léptékű és közvetlenebb bi- és trilaterális együttmúködések... erősödését jelentik, mindenekelőtt a schengeni belsô határok mentén".

A Kárpát-medencei határokon átnyúló természetvédelmi területek helyzetét az egyes országok eltérő történelmi háttere, szemlélete is befolyásolja. Kétségtelen, hogy a természetvédelemnek a 19. század közepétől egyre erősödő és tudományosan megalapozott egységes érvényesülését széttörte a történelmi Magyarország megszűnte, az új határok létrejötte. Bár ezt követően az utódállamokban is születtek rendelkezések a természetvédelem szolgálatára, de sajnos a Kárpát-medence egészét érintő összehangolt rendelkezésekre nem került sor (FODOR I. et al. 2012).

Csak pár példát kiragadva Szlovákiában kezdetben a korábbi magyar, majd a csehszlovák, végül az önálló szlovák rendelkezések határozták meg a természetvédelmet Ezek többnyire igazodtak a nemzetközi egyezményekhez. Kiemelendő, hogy Szlovákia területének 19,7\% -a (972 216 ha) valamilyen kategóriában védett terület, és a védett területek egy része határ menti térségben található. Az egykori „első” Csehszlovákia legkeletibb része, a határok gyakori átrendezése miatt többször is változó hovatartozású Kárpátalja a Kárpát-medence természeti értékekben talán egyik leggazdagabb térsége volt, Európaszerte kevés olyan vidék van, amely vetekedhetett az itt található zöldövezeti területek mennyiségével és minőségével. Azonban az ismert politikai és nehéz gazdasági viszonyok miatt a természetvédelem lehetőségei szerények, nagyméretű az erdőirtás, a nyilvántartott közel 200 keményszárú faj közül 44-et a kipusztulás veszélye fenyeget. Romániában egy 1950-ben született törvényerejü rendelet volt az első fontosabb természetvédelemmel kapcsolatos határozat, amely a „természeti kincsek” védelmét nemzeti érdeknek tekintette. Létrejött egy Természetvédelmi Bizottság, amelynek fó célkitűzése a természeti kincsek felleltározása, újabb objektumok védelem alá helyezésére javaslatok kidolgozása, a rezervátumok tudományos kutatásának megszervezése stb. volt. A jó elgondolások 
mellett azonban több, az élővilágot negatívan érintő negatív döntés is született, például megkezdődött a farkasok kiirtása, a halevő és ragadozó madarak irtása, a borókások és törpefenyvesek kivágása a havasi legelők kiterjesztése érdekében, valamint a lombhullató erdők, főleg a bükkösök kivágása a helyükbe telepítendő vörös- és duglászfenyő-ültetvények céljából stb. Ugyanakkor fokozatosan ratifikáltak olyan törvényeket, amelyekkel Románia csatlakozott a különböző nemzetközi egyezményekhez, és az Európai Unióba való belépés érdekében korábban soha nem látott mértékben megnövelték a - részben határok mentén is húzódó - védett természeti területek számát és kiterjedését (BARTóK K. 2006, 2012). A volt Jugoszlávia Kárpát-medencéhez sorolható területein kevés igazán jelentős természetvédelmi terület található. A 20. század második felében a határ menti térségek helyzetét - az osztrák-magyar határhoz hasonlóan - sajátosan befolyásolta a politika, megközelítésüket magyar oldalon erősen korlátozták. A határvédelem nyomai (futóárkok, bunkerek, géppuskafészkek) helyenként ma is láthatók. Az elzártság eredményeképpen a korábban múvelt területek gazdátlanul maradtak, a vidék elvadult, természetes úton erdósülni kezdett. Sok helyütt a természetszerú erdőket lecserélték nemesnyárasokra, de pl. a Mura árterében az erdőállományt a mai napig túlnyomórészt a termőhelynek megfelelő, őshonos fafajok alkotják.

A 20. század végén minden egyes volt ún. szocialista országban lejátszódott politikai fordulat minden ellentmondásai ellenére új és kiváló lehetőséget jelentett a természet- és tájvédelem terén két-, három-, sőt többoldalú együttmúködésekre. Kialakult együttmúködések, sikeres közös pályázások eredményeképpen Magyarország mai határai mentén jelenleg már létezik több valamilyen formában a természet- és tájvédelemhez kötődo, határon átnyúló szerveződés (2. táblázat).

2. táblázat - Table 2

Néhány jelentősebb határon átnyúló védett vagy részben védett terület Magyarország államhatára mentén (https://www.ramsar.org és www.unesco.org nyomán, kiegészítve) Some transboundary protected or partly protected areas along the political border of Hungary (by https://www.ramsar.org and www.unesco.org, completed)

\begin{tabular}{|c|c|c|}
\hline Név & Típus & Országok \\
\hline $\begin{array}{l}\text { Az Aggteleki-karszt és a } \\
\text { Szlovák-karszt barlangjai }\end{array}$ & $\begin{array}{l}\text { UNESCO világörökségi } \\
\text { helyszín (természeti) }\end{array}$ & Magyarország-Szlovákia \\
\hline $\begin{array}{l}\text { Fertő/Neusiedlersee } \\
\text { kultúrtáj }\end{array}$ & $\begin{array}{l}\text { UNESCO világörökségi hely- } \\
\text { szín (kulturális - kultúrtáj) }\end{array}$ & Magyarország-Ausztria \\
\hline $\begin{array}{l}\text { Baradla-Domica barlang- } \\
\text { rendszer }\end{array}$ & ramsari vizes élőhely & Magyarország-Szlovákia \\
\hline Ipoly-völgy-Poiplie & ramsari vizes élőhely & Magyarország-Szlovákia \\
\hline $\begin{array}{l}\text { Neusiedler See-Seewinkel } \\
\text {-Fertó-Hanság }\end{array}$ & ramsari vizes élőhely & Magyarország-Ausztria \\
\hline Felső-Tisza-völgy-Tisa & ramsari vizes élőhely & Magyarország-Szlovákia \\
\hline $\begin{array}{l}\text { Gemenc-Béda-Karapan- } \\
\text { csa-Kopácsi-rét (Kopački } \\
\text { rit)-Felső-Dunamellék } \\
\text { (Gornje Podunavije) }\end{array}$ & ramsari vizes élőhely & $\begin{array}{l}\text { Magyarország-Horvátország } \\
\text {-Szerbia }\end{array}$ \\
\hline Mura-Dráva-Duna & bioszféra-rezervátum & Magyarország-Horvátország \\
\hline Novohrad-Nógrád & geopark & Magyarország-Szlovákia \\
\hline Írott-kő-Geschriebenstein & natúrpark & Magyarország-Ausztria \\
\hline
\end{tabular}


Két olyan jelentősebb határon átnyúló táj - a Gömör-Tornai-karszt, illetve a Fertő vidéke - van, amelynek jelentős részei egyszerre bioszféra-rezervátumok, Natura 2000-es területek, illetve ramsari vizes élőhelyek, ráadásul nemzeti parkok részei, és felkerültek a világörökségek listájára is (természetesen a különböző kategóriákhoz tartozó területek határai nem esnek egybe).

Védett területek határon átnyúló együttmúködésének kérdéskörét, azon belül az integráció szintjét és problémáit a 2. táblázatban említett térségek közül az Írottkő-Geschriebenstein Natúrpark esetében vizsgálták részletesen egy európai uniós projekt keretében, elsősorban a területfejlesztés szempontjából. A natúrparkok jogi szempontból nem számítanak ugyan intézményesített védett területnek, a magyar állami természetvédelem hivatalos honlapján a védett természeti területek és értékek ismertetésében nem szerepelnek (legfeljebb felölelhetnek hivatalosan védett területeket is), tájvédelmi szempontból viszont jelentősek. A Magyar Natúrpark Szövetség meghatározása szerint a natúrparkok az ország jellegzetes természeti, tájképi és kultúrtörténeti értékekben gazdag területein, helyi közösségek által létrehozott tájszintű együttmúködések, amelyeknek célja a természeti és kulturális örökség megőrzése, bemutatása és a vidék fejlődését elősegítő hasznosítása. HeINTEL, M. et al. (2015) igen alapos tanulmánya számos szempontból elemzi a határon átnyúló natúrpark helyzetét, tanulságai az egyéb természetvédelmi megközelítésú együttmúködések számára is hasznosíthatók. A szerzők rámutatnak arra, hogy a védett területek alkalmas eszközt jelentenek a határon átnyúló együttmúködés elősegítésére, bár az eltérő kategóriák (például bioszféra-rezervátum, natúrpark, nemzeti park stb.) mindegyike egyedi esetet képvisel. A nagyfokú biodiverzitásra és az általuk reprezentált tájtípusok sokszínúségére alapozva közös cél ökológiai hálózatok létrehozása a táj egyensúlyának védelmére. A védelem mellett fontos a hasznosítás is, aminek fó elemeit HAMMER, T. et al. (2007) nyomán így foglalják össze: erőforrások feltárása, a regionális gazdaság megerősítése, a regionális arculat (imázs) felértékelése és a regionális identitás elősegítése, valamint a kultúrtáj megtartása és integrált továbbfejlesztése; mindezek elősegítik a határterületek gazdasági (fenntartható) fejlődését. Nemcsak a regionális fejlődést és értékteremtést kell segíteni, hanem biztosítani kell a helyi lakosság életminőségét is, ami a természetvédelem, mezőgazdaság, turizmus, kis- és kézmúvesipar, illetve a kultúra terén megvalósuló együttmúködések mellett marketing-és információs anyagok létrehozását, környezetbarát turizmus kialakítását, régiós munkahelyek létrehozását és helyi termékek előtérbe helyezését is igényli. Az együttmúködés korlátait illetően megállapítják, hogy a politikai határok visszafoghatják a fentiek megvalósítását, és az EU-s programok bürokráciája, valamint egyes sikeres modellek kiterjeszthetőségének hiánya a regionális fejlesztésben és együttmúködésben is akadályokat jelent. Problémaként említik még többek között a nyelvi akadályokat, a - nemzeti szinten is - periferikus helyzetet, a határon átnyúló együttmúködés gyér hagyományait, az a tényt, hogy számos kezdeményezés párhuzamosan, nem összehangoltan halad, továbbá hogy gyakran hiányzik egy központi koordináló személy. A szerzők szerint akadályozó tényező a pénzügyi keretfeltételek eltérô volta is, és nehezen leküzdhetôk a továbbra is meglévő mentalitásbeli különbségek.

Szomszédaink közül Ausztria mellett a legtöbb határon átnyúló kapcsolat Szlovákiával alakult ki. A továbbiakban két Szlovákia határai mentén fekvő - határon átnyúló, de különböző típusú - természet- és tájvédelmi szempontból kiemelkedő jelentőségú térség, illetve szerveződés kapcsolatrendszerének néhány elemét villantjuk fel.

\section{Az. Aggteleki Nemzeti Park és a Szlovák-karszt Nemzeti Park}

Annak, hogy a politikai határok mesterségesen vágnak ketté teljesen egyveretű tájakat, egyik legjobb példája éppen a magyar-szlovák határ mentén fekvő Gömör-Tornai- 
karszt. A szocializmus évei alatt nemcsak a határ két oldalán élő emberek, hanem a helyi kormányzatok, az intézmények és szakemberek között is nehéz volt kapcsolatok kialakítása, ápolása. E viszonynak mondhatni a jelképe volt az a rács, amely a természet által létrehozott egységes Baradla-Domica barlangrendszer két részét a föld alatt mesterségesen elzárta egymástól. Csak a politikai fordulat, majd az önálló Szlovák Köztársaság létrejötte után kezdődhetett meg az az együttmúködés, amelynek legelső hatalmas eredményeként a magyarországi Természetvédelmi Hivatal Barlangtani Intézete, az Aggteleki Nemzeti Park Igazgatóság, a Szlovák-karszt Tájvédelmi Körzet és a Szlovákiai Barlangok Igazgatósága munkatársai - akik közül a teljesség igénye nélkül szlovák részrôl JOzEF Klinda, Pavel Bella és Mikulás RozložníK, magyar részről Tardy János, SzéKely Kinga, BAROSS GÁBOR és TAKÁCSNÉ Bolner KATALIN nevét kell kiemelni - együttmúködésének köszönhetően Az Aggteleki-karszt és a Szlovák-karszt barlangjai 1995. december 9-én elnyerték az UNESCO Világörökség címet (KLINDA, J. 2015, TARDY J. - SzÉKELY K. 2015). A kapcsolat azóta is töretlen, a határ menti Aggteleki Nemzeti Park Igazgatóság és Szlovák-karszt Nemzeti Park Igazgatóság, illetve hivatali feletteseik között folyamatos az együttmúködés (GAÁL L. et al. 2015, GRUBER P. 2015). Évente legalább egyszer a két fél legmagasabb - helyettes államtitkári, foosztályvezetői - szinten, az erre a célra létrejött munkacsoport ülése keretében megvitatja az éves szakmai programot, beszámol az elmúlt év eredményeiről, megtervezi a szükséges további kutatásokat, intézkedéseket, amelyeket aztán a Magyar-Szlovák Környezetvédelmi és Természetvédelmi Vegyes Bizottság hagy jóvá. A két fél rendszeresen közös pályázatokat készít elő, majd nyújt be, amelyek közül több el is nyerte a kért támogatást. Közülük érdemes kiemelni a karsztvidék mélyebb tudományos feltárására - így hidrogeológiai kapcsolatok vizsgálatára, a morfológia és élővilág felmérésére, a felszíni eredetű szennyeződések feltárására és megelőzésére irányult, többek között környezetföldtani vizsgálatok, bioindikációs fajmeghatározások, mikroklímamérések, barlangi üledékek kormeghatározása, valamint háromdimenziós térképezés segítségével lezajlott vizsgálatokat. De hasonlóképpen jelentősek voltak a gyógyturisztikai fejlesztésekre, a madárvédelemre, a nagytestú ragadozókkal kapcsolatos kutatásokra és a Sajó, valamint a Hernád folyók és mellékvizeik természetvédelmi célú felmérésére irányuló pályázatok. A két fél szakemberei nagyon jó és közvetlen napi kapcsolatban állnak. Legújabban Az Aggteleki-karszt és a Szlovák-karszt világörökség barlangjainak kezelése címú pályázati projekt keretében végzett kutatások hoztak számos új tudományos eredményt (pl. egyes barlangok vízgyưjiő területeinek pontos kijelölése, karsztsérülékenységi térkép készítése). A tudományos tevékenység eredményeképpen számos közös kétnyelvú barlangtani, botanikai, zoológiai publikáció is megjelent az elmúlt évben, valamint a Baradla-Domica barlangrendszer átfogó monográfiája (GRUBER P.-GAÁL L. 2014) is.

A két fél számos határon átnyúló közös programot is lebonyolít. Ízelítőuil csak néhányat kiemelve összehangoltan folyik a felszíni ökoturisztikai szolgáltatások minőségi fejlesztése, lehetőségeinek kiépítése a természetjárás, kerékpáros turizmus és a lovas turizmus számára. (Utóbbi terén folyik egy nemzetközi lovastúra-útvonal kialakítása, és cél nemzetközi lovastáborok szervezése.) Magyarországi és szlovákiai oldalon egyaránt folyamatban van egy összehangolt bemutatási rendszer kialakítása, amelynek elemei pl. a bemutatóhelyek ismertető anyagai, ismeretterjesztő kiadványok, honlap, facebook-oldal egységes arculati megjelenése, összehangolt turisztikai programszervezés és programajánlás, egységes közös marketing és kommunikáció tervezése és megvalósítása, az egységes látogatás feltételrendszerének kidolgozása (pl. kedvezményes látogatójegy biztosítása bizonyos területek megtekintése esetén). Új feladat egy leendő csillagoségbolt-park megvalósításához mindkét oldalon helyszínek kijelölése. 
Közös fejlesztések keretében valósul meg a kulturális örökségek védelme is, valamint a Világörökség területére eső barlangokban a régészeti és őslénytani értékek felkutatása, megőrzése és bemutatása. A Sajón és a Hernádon végzett felméréseket követően most a Bodrog és Bódva hasonló jellegú közös kutatása van soron. Jelentős közös fejlesztés a térség első, határon átnyúló túraútvonala, a foglalkoztató jellegú Zöld Határ tanösvény, amely a Baradla-Domica barlangrendszer aggteleki és domicai bejáratát köti össze mintegy 7 km hosszan, és a tanösvény 11 állomása a látogatót megismerteti a terület természeti sajátosságaival, növény- és állatvilágával, az ember és természet kölcsönhatásaival, részben játékos feladatokkal kiegészítve. Fontosak a határon átnyúló környezeti nevelési programok, amelyek mind magyarországi, mind szlovákiai iskolákra kiterjednek; ezek fóbb elemei a témanapok, a terepi foglalkozások és az erdei iskolai programok. Saját program az ún. Zöld Sziget, ami térségi fesztiválokhoz, szabadidős programokhoz kapcsolódó, bemutatkozó kitelepülés. Ez azért is fontos, mert az ökoturisztikai célok megvalósításához szükséges a helyi lakosság és vállalkozók bevonása. Az ökoturisztikai szolgáltatások fejlesztése mellett az egészségturizmus is kiemelt célterület, ám - ha el is tekintünk a jogi kérdésektől és a szükséges minősítések megszerzésétől - mindkét oldalon jelentős infrastrukturális fejlesztés is szükséges lenne a gyógyturisztikai tervek végrehajtásához. Közös feladatként halad a geoturisztikai bemutatórendszer (látogatóhelyek, bányák, alapszelvények, földtani feltárások stb.) kiépítése, modern információs eszközökkel való ellátása. Az élővilág védelme területén az említett fajmegfigyeléseken túl csak közösen lehet elérni az inváziós növényfajok elterjedésének visszaszorítását.

Noha a térség ökoturisztikai fejlesztése jelentôs, a barlangrendszerek pedig fontos turisztikai vonzerôt jelentenek, a látogatók száma mégsem mutat jelentős emelkedést, sőt az elmúlt években inkább stagnál (3. táblázat). A szlovákiai oldal adatai magasabbak, de csak azért, mert a Világörökség része lett két olyan távolabb fekvő, látogatott barlang is, amelyek nem a Gömör-Tornai-karszt részei, egyébként a látogatottság a Szlovák-karszt Nemzeti Park barlangjaiban sem kiugró és eléggé hullámzó. Ennek fő oka minden bizonnyal a megközelíthetőség nehézségében keresendő, hiszen a karsztvidékre egyik oldalon sem vezet korszerú múút vagy vasút, még a legközelebbi autópályától sem könnyű Aggtelekre, Jósvafőre, vagy Kecsőre, Szilicére, Várhosszúrétre eljutni. Minden bizonnyal ezzel magyarázható az is, hogy a barlangok - különösen a Baradla - kiemelkedő nemzetközi értéke és rendkívüli látványossága ellenére a látogatók közt a külföldiek száma nem jelentős, nagyjából $10 \%$ körüli (4. táblázat), de legalább itt érzékelhető egy viszonylag folyamatos növekedés. Bár pontos adatok nem állnak rendelkezésre, tapasztalható, hogy a látogatók legnagyobb részét adó, autóbusszal érkező turistacsoportok általában nem lépik át a határt, a karsztvidék másik országra eső részét nem keresik fel. Sőt, magán a karsztvidéken is általában csak egy napot, vagy még inkább azon belül néhány órát töltenek el, nem többet, mint amennyi a barlanglátogatáshoz (és esetleg egy étkezéshez) szükséges. E téren óriási a különbség az osztrák-magyar határ menti határon átnyúló védett területekhez képest, ami hosszú távon mindenképpen intézkedéseket igényel. Legalább ilyen fontos lenne a szezon széthúzása, hiszen jelenleg a látogatók több mint fele, sőt egyes években közel kétharmada a május eleje - augusztus vége közötti négy hónapban keresi fel a világörökségi helyszínt.

\section{A Novohrad-Nógrád Geopark}

A Magyarország határain átnyúló szerveződések közül különös figyelmet érdemel a Novohrad-Nógrád Geopark (NNG), ugyanis a geoparkok azok a szerveződések, amelyek létrejöttében a földtudományi értékek alapvető szerepet játszanak. A geopark alapvetóen egy térségfejlesztési koncepció, olyan terület, amely földtudományi - földtani, felszín- 


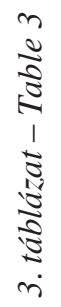

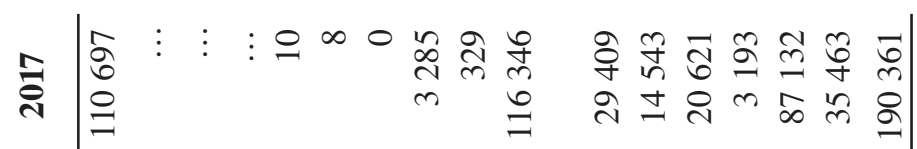

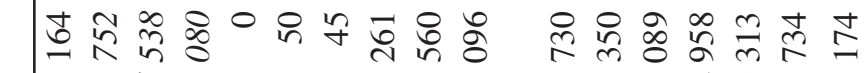

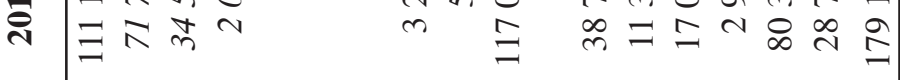

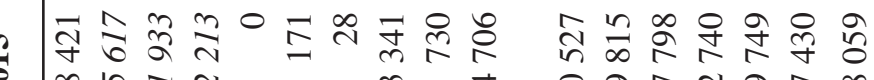

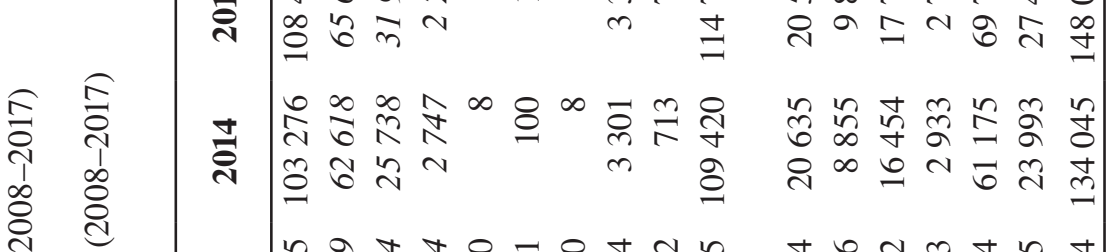
वृ

(⿹勹巳)

苞 일. 을 흔 政类 ๘

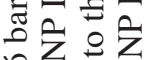
过这

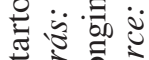
N $\begin{gathered}0 \\ 0\end{gathered}$

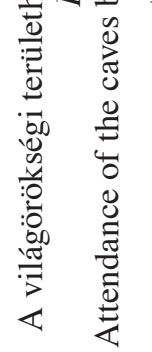

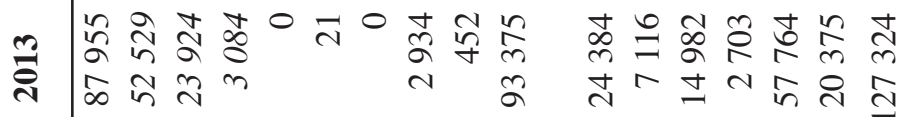

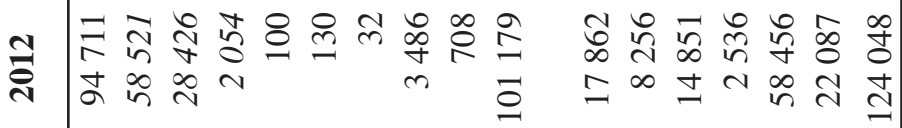

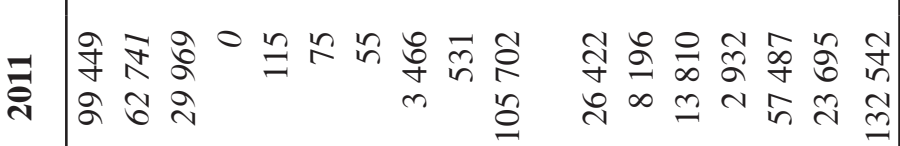

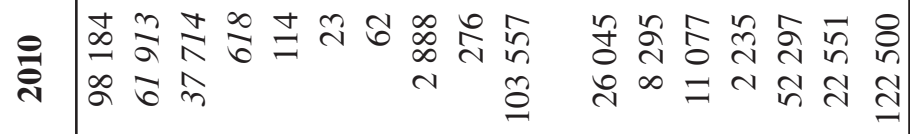

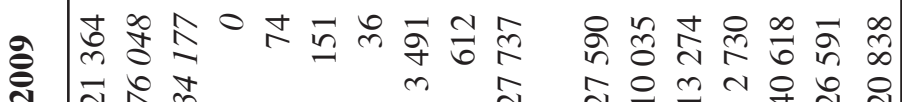

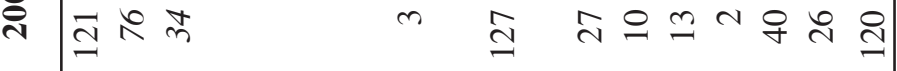

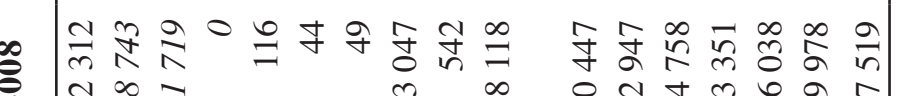

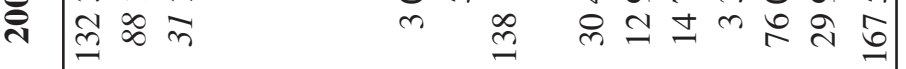

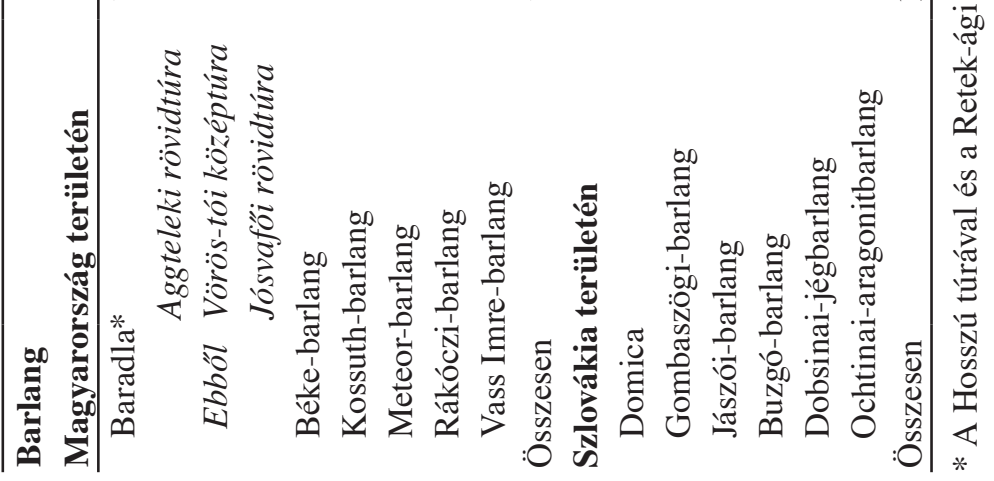


Az Aggteleki Nemzeti Park barlangjainak látogatottsága külföldiek által (2011-2017).

Forrás: ANP Igazgatóság

Attendance of the caves of the Aggtelek National Park by foreign citizens (2011-2017).

Source: ANP Directorate

\begin{tabular}{|c|c|c|c|c|c|c|c|c|}
\hline \multicolumn{2}{|c|}{ Barlang } & 2011 & 2012 & 2013 & 2014 & 2015 & 2016 & 2017 \\
\hline \multirow[t]{3}{*}{ Baradla } & $\begin{array}{l}\text { Aggteleki } \\
\text { rövidtúra }\end{array}$ & 8419 & 7347 & 7974 & 9066 & 8897 & 10922 & 13444 \\
\hline & $\begin{array}{l}\text { Vörös-tói } \\
\text { középtúra }\end{array}$ & 1948 & 2022 & 2812 & 2885 & 3002 & 2661 & 551 \\
\hline & $\begin{array}{l}\text { Jósvaföi } \\
\text { rövidtúra }\end{array}$ & 0 & 110 & 64 & 37 & 143 & 48 & 136 \\
\hline \multicolumn{2}{|c|}{ Rákóczi-barlang } & 231 & 105 & 140 & 231 & 350 & 209 & 237 \\
\hline \multicolumn{2}{|c|}{ Vass Imre-barlang } & 19 & 18 & 18 & 23 & 19 & 39 & 8 \\
\hline \multicolumn{2}{|c|}{ Összesen } & 10617 & 9602 & 11008 & 12242 & 12411 & 13879 & 14376 \\
\hline
\end{tabular}

alaktani, víztani, talajtani - értékekben, képződményekben, formákban, bányászati, bányászattörténeti emlékekben különösen gazdag. Emellett számottevő kulturális értékekkel is rendelkezik, és ezen örökség objektumaira építve holisztikus egységként jeleníti meg a természetvédelem, a környezeti nevelés, az ismeretterjesztés, a kutatás és a térségfejlesztés törekvéseit, ezáltal új lehetőségeket teremt a vidék jövőjének formálásában és a földtudományi örökség jelentőségének megismertetésében, ugyanakkor elősegíti a földtudományi változatosság (geodiverzitás) védelmét is (TARDY J. et al. 2018). A geoparkokat összefogó, az UNESCO által koordinált Globális Geopark Hálózathoz 2018-ban 35 ország 127 helyszíne (ezen belül Európában 23 ország 70 helyszíne) tartozik. A két magyarországi UNESCO Globális Geopark közül a magyarországi és szlovákiai területeket is felölelő, 2010-ben létrejött Novohrad-Nógrád Geopark a Föld első határon átnyúló geoparkja volt. Az alulról jövő kezdeményezésre megindult és néhány kiváló személyiség - külön ki kell

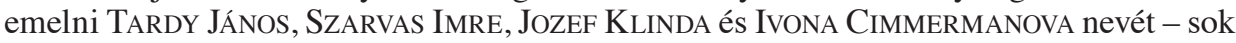
éves munkájával létrejött, az Európai Geopark Hálózat által 2010-ben befogadott geopark főként a történelmi Nógrád vármegye egy részét öleli fel, és egyik célja, hogy a politikai határ által kettévágott nógrádi tájat és a határ két oldalán élő közösségeket a határok nélküli Európa lehetőségeit kihasználva geoturizmus komplex térségfejlesztési lehetőségeivel újra egyesítse, ilyen értelemben tehát kiválóan jelképezi és megtestesíti azokat az elveket és célokat, amelyeket a határon átnyúló védett térségekkel és együttmúködésekkel kapcsolatban az IUCN WCPA és az EUROPARC Federation megfogalmazott.

A geopark cím megszerzése ma már éppen olyan nehéz, mint a világörökségi címé. Mindkettó nagyon vonzó, mert a cím elnyerése rendkívüli mértékben megnöveli az érdeklődést az adott terület iránt nemzetközi szinten is, ami elősegíti a gazdasági fejlődést keltő turizmus - geopark esetében leginkább az öko- és geoturizmus - fellendülését. A cím megtartásához négy évenként hivatalos újraértékelés szükséges, aminek kedvező elbírálásához a geoparkot irányító szervezetek, a szlovákiai és magyarországi önkormányzatok és szakemberek magas fokú együttmúködésére van szükség. A geopark esetében ugyanis kiemelkedő szerepe van az önkormányzatok együttmúködésének, különösen a térség két legjelentősebb városa, Salgótarján és Fülek önkormányzatának szerepe meghatározó, és mivel nagyobb apparátus nem áll a geopark mögött, óriási jelentősége van a vezető és a támogató személyiségeknek. A kezdeti nehézségeket követően az elmúlt években a NNG helyzete stabilizálódott. A magyarországi és a szlovákiai irányító szervezetek szerény 
mértékben ugyan, de növelni tudták az alkalmazottak számát, akik menedzselik a mindennapi munkát és folyamatos kapcsolatban állnak egymással. A 4 fős magyarországi és a 2 fős szlovákiai menedzsment külön-külön, a helyi és az országos természetvédelmi és igazgatási szervezetekkel együttmúködve intézik a geopark ügyeit, de összehangoltan, a fontos stratégiai kérdésekben paritásos alapon közösen döntve. A menedzsmentek nehéz feladata - a néha eltéró érdekek, igények, elképzelések ellenére - a geoparki településeket, azok társadalmi csoportosulásait, a geopark értékeit védő szerveket, a segítő oktatási intézményeket és a geoparkban érdekelt vállalkozásokat összefogni, a geoturizmus és örökségvédelem szolgálatába állítani a térség fejlesztése és környezeti jóléte érdekében.

A programok és a pályázati úton elnyerhető fejlesztési lehetőségek a határ mindkét oldalán ösztönzik az önkormányzatokat, a helyi irányító szerveket és a civil szervezeteket arra, hogy szorosabbra fonják együttmúködésüket, elősegítve ezzel a két ország közötti kapcsolatok javulását is. Azonban a sok pozitív eredmény ellenére megállapítható, hogy a határon átnyúló Írott-kő-Geschriebenstein Natúrparkkal kapcsolatban HEINTEL, M. et al. (2015) vizsgálatait összegző tanulmányból fentebb idézett megállapítások jelentôs mértékben érvényesek a NNG-ra is, a geopark problémái sok tekintetben hasonlók a natúrparkéhoz. Egyik legfontosabb tényező a biztos és rendszeres pénzügyi háttér hiánya. Kétségtelen, hogy a Bükki Nemzeti Park Igazgatósága (BNPI) jelentős támogatója a geoparknak, már csak azért is, mert a geopark területén a BNPI által igazgatott tájvédelmi körzetek is találhatók, és a geopark egyik kiemelkedő jelentôségú, legnagyobb látogatottságú és az elmúlt években legnagyobb mértékben fejlesztett helyszíne, az ipolytarnóci ősmaradványbemutatóhely is a BNPI-hoz tartozik. Az aggteleki térséggel is van több hasonlóság, mint például az infrastruktúra hiányossága és a többnyire nem kielégítő közlekedési helyzet; példaként elég, ha a világhírü, Európai Diplomát is elnyert Ipolytarnóci Ôsmaradványok Természetvédelmi Terület igen nehéz megközelítését említjük.

A NNG alapvető tevékenységét a geoturisztikai fejlesztések jelentik, amelynek részben az egyes országok regionális fejlesztési programjai keretében meghirdetett pályázatokban, részben pedig közösen benyújtott és elnyert nemzetközi (Visegrádi Alap, Interreg stb.) pályázatokban kitűzött integrált fejlesztési célok megvalósítása révén valósultak és valósulnak meg. A viszonylag nagy kiterjedésű geoparkban a fejlesztések zöme néhány kivételtől (mint például az UNESCO világörökség részét alkotó Hollókő, vagy a földtani ritkaságot bemutató Bér térsége) eltekintve jobbára az északi, határ menti területekre terjedt ki, itt épült meg pl. az új eresztvényi Oktató-, Kutató- és Irányítóközpont, valamint a salgóbányai egykori bányakaszinó épületének felújításával a Geocsodák háza (2.ábra), és Füleken is új geoparki iroda nyílt. Ezeket alapvetóen pályázati forrásokból elnyert támogatások tették lehetővé, ami nagy siker, de a fenntartást és a további fejlesztést erősen kétségessé teszi, ha csak a bizonytalan pályázati lehetőségekre lehet támaszkodni. A további fejlesztési tervek inkább az államhatártól távolabb fekvő területeket célozzák meg.

Számos, az integrált fejlesztést célzó közös program valósult meg, különösen az új látogató- és oktatóközpontok révén, amelyek információnyújtási szerepükön túl változatos programokat szerveznek az érdeklődők számára, és ezekben - mint minden hasonló parkban - kiemelt szerepet kap a környezeti nevelés. A jelesebb programok közül kiemelhető az Európai Geoparkok Hete keretében lebonyolított Vulkánnap, a rendszeres nyári tábor 8-14 éves gyermekek számára és a rendkívül népszerú, közel 2500 amatőr és profi fotóst megmozgató, 2013 óta több ízben meghirdetett, immár nemzetközi hírúvé vált Medvesi Fotós Maraton fotópályázat. Évente mind több, részben a határt is átszelő vezetett geotúrára is sor kerül, amelyek keretében a látogatók megismerhetik a térség földtudományi, ipartörténeti - pl. bányászati - és kulturális értékeit. A geoparkban jelentős infrastrukturális és információs fejlesztések zajlottak le és jelenleg is folynak, köztük 


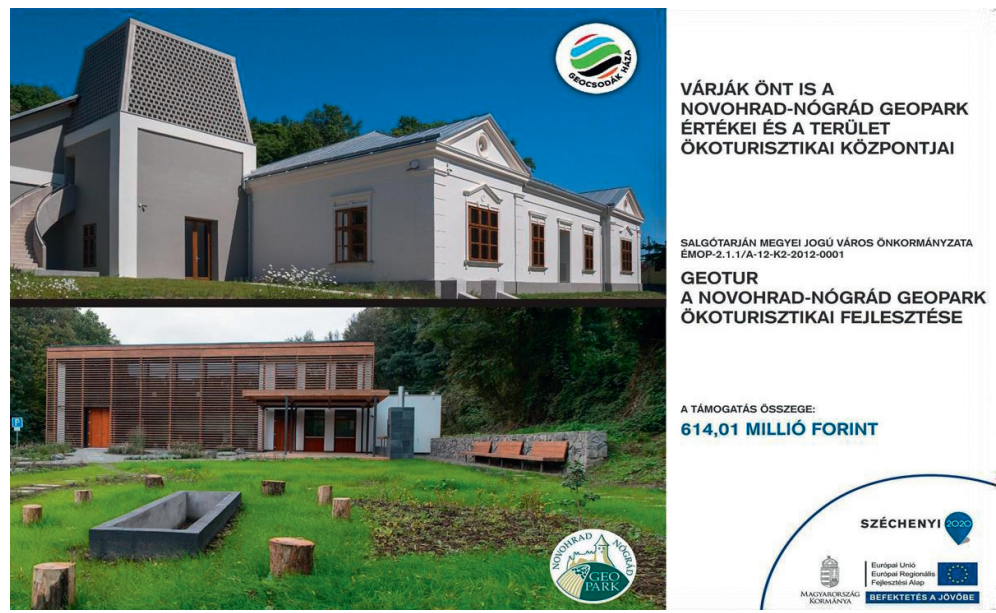

2. ábra Az ökoturisztikai fejlesztést hirdető tábla a Novohrad-Nógrád Geopark két új központjának fényképével (Forrás: Novohrad-Nógrád Geopark)

Figure 2 Table announcing the development on ecotourism showing the photos of the two new centres of the NovohradNógrád Geopark (Source: Novohrad-Nógrád Geopark)

gyalogos és kerékpáros túraútvonalak kiépítése, háromnyelvű (magyar, szlovák és angol) ismertető táblákkal ellátott tanösvények kijelölése és karbantartása, valamint ugyancsak többnyelvű, vagy több nyelven is megjelentetett oktató és ismertető füzetek kiadása. Ezek a turisztikai marketingnek is fontos elemei, a megvalósítás során törekedve arra, hogy azokat egységes arculat és megjelenés jellemezze. Külön meg kell említeni az Ipoly folyón a közelmúltban újjáépült hidakat (a NNG területén ezek Pösténypusztánál a Katalin híd és Ráróspusztánál a Madách híd), amelyek nemcsak valóságos összeköttetést biztosítanak a két ország között, hanem szimbolikus értékük is kiemelkedő jelentőségú. Új lehetôséget jelentenek az országhatár vonalában tervezett vagy már létező kerékpárutak. A turisztikai kínálat tehát jelentős, de szükséges a szálláshelyek, vendéglátóhelyek számának növelése és minőségüik javítása. Fejlődőben van, de még számtalan kiaknázatlan lehetőséget kínál a helyi termékek turisztikai célú hasznosítása, ennek további bővítése erősítené a helyiek kötődését a geoparkhoz. A népszerú közösségi terek (pl. facebook) erőteljesebb bevonása pedig az ismertség növelését eredményezheti.

A geopark látogatottságát nehéz pontosan megítélni, mivel számos helyszínen nincs mód az érkezők regisztrálására. A legismertebb helyszínekről azonban vannak friss adatok 2017-ről (5. táblázat), amelyek ezen kiemelkedő helyszínek iránti jelentős érdeklődésről tanúskodnak. Egyre többen vesznek részt a Geopark által meghirdetett kirándulásokon, a Világ Gyalogló Nap és a Geotóp Nap rendezvényein stb. A látogatók lakóhelyi szerinti megoszlása (helyben élők 50\%, egyéb Nógrád megyei 10\%, egyéb belföldi $35 \%$, külföldi $5 \%$ ) azonban azt jelzi, hogy jóval alaposabb marketingtevékenységre van szükség ahhoz, hogy a turizmus a jelenleginél még sokkal jelentősebb területfejlesztő erôvé váljon.

\section{Összefoglalás}

Összegezve megállapítható, hogy a kisebb nehézségek ellenére a határon átívelő Novohrad-Nógrád Geopark tevékenysége a régiók területfejlesztési lehetôségein túl azért is előnyös, mert ösztönzi az önkormányzatokat, a helyi irányító szerveket és a civil 
A Novohrad-Nógrád Geoparkban 2017-ben regisztrált látogatók száma a geopark eresztvényi központjának összesítése alapján

Number of visitors recorded in 2017 in the Novohrad-Nógrád Geopark summing up by the centre of the geopark in Eresztvény

\begin{tabular}{lr}
\hline Ipolytarnóci Ôsmaradványok Természetvédelmi Terület & 48000 \\
Baglyaskő-Vár Természetvédelmi Látogatóközpont & 3400 \\
Eresztvényi Oktató-, Kutató- és Irányítóközpont & 7500 \\
Dornyay Béla Múzeum Bányászati Kiállítóhelye & 12000 \\
Hollókő (világörökségi helyszín) & 60000 \\
Mátraverebély-Szentkút (nemzeti kegyhely) & 100000 \\
Szécsényi Kubinyi Ferenc Múzeum & 12000 \\
Salgóbányai Geocsodák háza & 3000 \\
Füleki vár & 23800 \\
Somoskői tanösvény és vár & 26000 \\
Összesen & 294900 \\
\hline
\end{tabular}

szervezeteket a határ mindkét oldalán arra, hogy szorosabbra fonják együttmúködésüket, elősegítve ezzel a két ország közötti kapcsolatok javulását is. Mindenképpen egyet lehet érteni a Pangea címú internetes blog azon megállapításával, miszerint a geopark hatalmas lehetőség a nógrádi térségnek, amelyet a nemzetközi turizmus - a térség egyetlen világörökségi helyszíne, Hollókő kivételével - eddig jobbára elkerült.

E két magyarországi példa is jelzi, hogy a fennálló eltéró jogi, igazgatási és támogatási háttér különbségeitől függetlenül és az infrastrukturális elmaradottság ellenére érdemes mind nagyobb súlyt helyezni a többnyire perifériahelyzetben lévő határ menti területek természetvédelmi alapú együttmúködésének bővítésére, fejlesztésére.

\section{Köszönetnyilvánítás}

A szerzők ez úton köszönik meg az Aggteleki Nemzeti Park, a Novohrad-Nógrád Geopark és a Szlovákiai Barlangok Igazgatósága munkatársainak, különösen IGOR BALCIARnak, DreXler SZILÁRdnak, DVORSZKy ZsuZSAnnÁnak, GaÁl LAJOSnak, Gruber PÉTERnek, PraKfalvi PéTernek és SzARVAs ImRének, valamint Vincze PÉTERnek a tanulmány elkészítéséhez nyújtott segítségét. A tanulmány a 112477. számú OTKA-projekt támogatásával valósult meg.

\section{GÁlosi KovÁcs BERnADETT}

PTE TTK FFI Politikai Földrajzi, Fejlődési és Regionális Tanulmányok Tanszék, Pécs detty@gamma.ttk.pte.hu

HORVÁth GERGELY

ELTE TTK FFI Környezet- és Tájföldrajzi Tanszék, Budapest

horvger@caesar.elte.hu 


\section{IRODALOM}

BARAnYi B. 2007: A határmentiség dimenziói. - Dialóg Campus Kiadó, Budapest-Pécs. 318 p.

BARANYi B. 2014: Adalékok a határ mentiség újraértelmezéséhez Magyarországon. - The Central European Journal of Regional Development and Tourism 6. 2. pp. 26-45.

BARTóK K. 2006: Az élő természet védelme. A biodiverzitás védelme Romániában. - Ábel Kiadó, Kolozsvár. 170 p.

BARTóK K. 2012: Románia természetvédelmi területei, és fenntartásuk kezelési módszerei. Ábel Kiadó, Kolozsvár. 324 p.

Bulla B.-MendöL T. 1947: A Kárpát-medence földrajza. - Egyetemi Nyomda, Budapest. 611 p.

Carpathians Environment Outlook 2007. - United Nations Environment Programme, Geneva. 232 p.

CHassot, O. 2011: Ecological issues - Transboundary conservation. http://www.tbpa.net/page.php?ndx=46

Csorba P. 2008: A tájhatárok kijelölése és változása. - Földrajzi Közlemények 132. 2. pp. 220-226.

CsüLlÖG G. 2008. The role of borders in spatial structure changes. - In: SÜLI-ZAKAR I. (szerk.): Neighbours and partners: on the two side of the border. Kossuth Egyetemi Kiadó, Debrecen. pp. 13-18.

DöVÉnYi Z. (szerk.) 2010: Magyarország kistájainak katasztere. - MTA Földrajztudományi Kutatóintézet, Budapest. $876 \mathrm{p}$.

EUROPARC Federation (szerk.) 2010: Following nature's design. Promoting cross-border cooperation in nature conservation. - Heidehof Stiftung. 28 p. https://www.europarc.org/wp-content/uploads/2009/01/brochure_TransParcNet_final_low_resolution.pdf

FARAGÓ I. 2014: Földrajzi nevek. - Egyetemi jegyzet. ELTE, Budapest. 366 p.

FODOR I. 2008: Environmental management, risk prevention, natural and cultural heritage in the Carpathian area. - In: GÁL Z.-RÁcZ Sz. (szerk.): Socio-economic analysis of the Carpathian Area. Centre for Regional Studies of the Hungarian Academy of Sciences, Pécs. pp. 33-44.

Fodor I.-GÁlosi-Kovács B.-ZÁvodszky Sz.-Szabó Gy. 2012: Természet és környezet. - In: Dövényi Z. (szerk.): A Kárpát-medence földrajza. Akadémiai Kiadó, Budapest. pp. 332-374.

GaÁl L.-Bella, P.-Haviarová, D.-ZelinkA, J.-PAPÁč, V.-BAlCiar, I.-LABAŠKA, P. 2015: A szlovákiai világörökségi barlangok kutatásának, védelmének és kezelésének áttekintése 1995-től. - Aragonit 20. 1.pp. 40-44.

GRUBER P. 2015: Élettelen természeti értékek megőrzése, kutatása és kezelése az Aggteleki-karszton: Visszatekintés az elmúlt 20 évre. - Aragonit 20. 1. pp. 48-52.

GRUBER P.-GAÁL L. (szerk.) 2015: A Baradla-Domica-barlangrendszer - A barlang, amely összeköt. - Aggteleki Nemzeti Park Igazgatóság, Jósvafő. 512 p.

KLINDA J. 2015: A Szlovák- és Aggteleki-karszt Világörökség 20 éve. - Aragonit 20. 1. pp. 6-7.

Hajdú-Moharos J.-Hevesi A. 1997: A Kárpát-Pannon térség tájtagolódása. - In: Karátson D. (főszerk.): Magyarország földje: kitekintéssel a Kárpát-medence egészére. Kertek 2000 Kiadó, Budapest. pp. $274-284$.

Hammer, T.-Mose, I.-Siegrist, D.-Weixlbaumer, N. 2007: Protected areas and regional development in Europe: towards a new model for the $21^{\text {st }}$ century. - In: Mose, I. (szerk.): Protected areas and regional development in Europe. Towards a new model for the $21^{\text {st }}$ century. Ashgate Publishing, Aldershot. pp. $233-246$.

HARDI T. 2000: Államhatárok és regionális együttmúködések. - In: HoRvÁTH GY.-RECHNITZER J. (szerk.): Magyarország területi szerkezete és folyamatai az ezredfordulón. MTA Regionális Kutatások központja, Pécs. pp. 595-615.

Heintel, M.-Weixlbaumer, N.-Debre, B. 2015: Védett területek mint a határon átnyúló együttmúködés tényezői? Reflexiók az osztrák-magyar határ mentén lebonyolított ETE-projekt tapasztalatai alapján. - Tér és Társadalom 29. 4. pp. 117-138.

HoRvÁth G.-CsüllöG G. 2011: Geoconservation and geotourism in a new Central European geopark. - In: LiN J.-C. (szerk.): Landscape Conservation. National Taiwan University, Taipei, pp. 31-42.

HoRvÁth G.-CsÜllög G. 2014: Grenzen in Zentraleuropa. Eine geographische Annährung. - In: BALOGH F. A.-Leitgeb, CH. (szerk.): Reisen über Grenzen in Zentraleuropa. Praesens Verlag. Wien. pp. 155-167.

KÁDÁR L. 1941: A magyar nép tájszemlélete és Magyarország tájnevei. - Országos Táj- és Népkutató Intézet, Budapest. 24 p.

Kocsis K. 2004: A politikai és az etnikai földrajz határértelmezései. - In: KovÁcs N.-Osvát A.-SzARKA L. (szerk.): Tér és terep. Tanulmányok az etnicitás és az identitás kérdésköréből III. Akadémiai Kiadó, Budapest. pp. 23-28.

Kocsis K. 2006: A Kárpát-medence tájfelosztásának eddigi főbb hazai kísérletei. - In: Kocsis K.-BotTLIK Zs.-TÁTRAi P.: Etnikai térfolyamatok a Kárpát-medence határainkon túli régióiban (1989-2002). MTA Földrajztudományi Kutatóintézet, Budapest. pp. 9-20.

LuKÁCs L. 2006: Prinz Gyula tájszemlélete és tájneveinek kartográfiai vonatkozásai. - III. Magyar Földrajzi Konferencia tudományos Közleményei. MTA Földrajztudományi Kutatóintézet. 9 p.

LySENKO, I.-BESANÇON, C.-SAVY, C. 2007: UNEP-WCMC global list of transboundary protected areas. - 78 p. http://www.tbpa.net/docs/78_Transboundary_PAs_database_2007_WCMC_tbpa.net.pdf 
MARosi S.-Somogyi S. 1990: Magyarország kistájainak katasztere. - MTA Földrajztudományi Kutatóintézet. $1024 \mathrm{p}$.

Mezősi G.-BATA T. 2011: A földrajzi tájak határai. - Földrajzi Közlemények 135. 1. pp. 33-43.

Nemes Nagy J. 1998. A tér a társadalomkutatásban. - Hilscher Rezső Szociálpolitikai Egyesület, Budapest. 261 p.

PALÁdi-KovÁcs A. 2003: Tájak, népek, népcsoportok. - Akadémiai Kiadó, Budapest. 412 p.

PAP N.-Tóth J. 2008: The role of religious and ethnic minorities in disintegration of the state structure of Western Balkans. - Modern Geográfia 1. http://www. moderngeografia.eu/?p=738

Pool, C. 2006: Transboundary protected areas as a solution to border issues. - Nebraska Anthropologist. 23. pp. 41-57. http://digitalcommons.unl.edu/nebanthro/23

Prinz Gy. 1936: Magyarország tájrajza. - In: Prinz Gy.-Cholnoky J.-Teleki P.-Bartucz L.: Magyar föld, magyar faj I. Magyar földrajz. Királyi Magyar Egyetemi Nyomda, Budapest. 395 p.

SAndwith, T.-Shine, C.-Hamilton, L.-Sheppard, D. 2001: Transboundary protected areas for peace and co-operation. - Best Practice Protected Area Guidelines Series 7. IUCN, Gland. 11+111 p. http://www.tbpa. net/docs/110_IUCN_TBPA_guidelines.pdf

TARdy J.-Schmidt A.-CSEPREgi I.-Zsembery Z. 2018: Természetvédelem. - In: Kocsis K. (fószerk.): Magyarország Nemzeti Atlasza. Természeti Környezet. MTA CSFK FTI, Budapest. pp. 144-155.

TARDY J.-SzÉKELY K. 2015: Emlékezés az Aggteleki- és Szlovák-karszt Világörökség cím elnyerésére. - Aragonit 20. 1. pp. 12-15.

Tімотнy, D. J. 1995: Political boundaries and tourism: borders as tourist attractions. - Tourism Management 16. 7. pp. 525-532.

TóTH J. 1996: A Kárpát-medence és a nemzetközi regionális együttműködés. - In: PÁL Á.-SzÓNOKYNÉ ANCSIN G. (szerk.):: Határon innen - határon túl. JATE Gazdasági Földrajzi Tanszék, JGYFT Földrajzi Tanszék. Szeged.pp. 27-43.

TóTH J. 2011: A határokrul. - In: FrisnYÁk S.-GÁL A. (szerk.): Kárpát-medence: tájak, népek tevékenységek. Nyíregyházi Főiskola Turizmus és Földrajztudományi Intézete - Szerencsi Bocskai István Gimnázium, Nyíregyháza-Szerencs. pp. 441-473.

VARGA Z. 2000: Biológiai sokféleség a Kárpát-medencében, és a természet védelmének prioritásai. - In: FoDOR I.-KovÁcs B.-TÉsits R. (szerk.): Társadalom és környezet. Dialóg Campus Kiadó, Budapest-Pécs, pp. 133-146.

VAsilijević, M.-Zunckel, K.-McKinney, M.-Erg, B.-Schoon, M.-Rosen Michel, T. 2015: Transboundary conservation: a systematic and integrated approach. - IUCN Best Practice Protected Area Guidelines Series 23, Gland. 12+107 p. https://portals.iucn.org/library/sites/library/files/documents/PAG-023.pdf

Williams, P. 2008: World Heritage Caves and Karst. A thematic study. - IUCN World Heritage Studies 2. Gland. 34 + 16 p. https://www.iucn.org/sites/dev/files/import/downloads/cavesandkarstwh.pdf

Wimbledon, W. A. P.-Smith-Meyer, S. (szerk.) 2013: Geoheritage in Europe and its conservation. - ProGEO, Oslo. 405 p.

Woood, C. 2009: World Heritage Volcanoes. A thematic study. - IUCN World Heritage Studies 8. Gland. 62 p. https://www.iucn.org/sites/dev/files/import/downloads/whvolcanoes2.pdf

ZADEH, L. A. 1965: Fuzzy sets. - Information and Control 8. pp. 338-353.

\section{Internetes források}

EUROPARC https://www.europarc.org/

Global Transboundary Conservation Network http://www.tbpa.net/

Magyar Natúrpark Szövetség https://www.naturparkok.hu/hu/

Magyar Állami Természetvédelem http://www.termeszetvedelem.hu/

Pangea blog https://pangea.blog.hu/

ProGEO http://www.progeo.ngo

World Commission on Protected Areas https:/www.iucn.org/theme/protected-areas/wcpa 